\title{
Women Naming Women: The Use of Sobriquets by Aphra Behn, Anne Finch, and Katherine Philips
}

\author{
Martha Rainbolt \\ Depauw University
}

\begin{abstract}
Sobriquets were commonly used by British writers of the late 16th and 17th centuries. The sobriquets chosen by Aphra Behn, Anne Finch, and Katherine Philips, the three central women poets of the period, their literary sources, and their associations and significance are discussed. Each of the three writers names herself and her friends and in so doing transcends the alternatives of invisibility or notoriety, apparently the only choices available to women writers of the time. By using sobriquets, the writers identify themselves and their friends as inhabitants of a different and unorthodox world, but one which includes recognition as writers and as members of a community of writers.
\end{abstract}

\section{Introduction}

Katherine Philips, Aphra Behn, and Anne Finch are at the center of a group of British women poets writing in the 17th century. The later of the three (Behn and Finch) authenticate themselves and their poetry by drawing upon the prestige of the earlier (Philips). Together they create a world outside that of male dominance and one of the more intriguing ways in which they create this world is by their use of sobriquets. (I am using the more general term sobriquet rather than nom de plume or pseudonym, because the latter two terms refer to writers naming themselves. Philips, Behn, and Finch do name themselves, but they also name one another and their friends, both women and men.) Through this naming process, they give an identity to themselves and a validity to their work; they also create an alternate world, one which is inhabited by their own creations.

Women, of course, have always been named by men and breaking this convention had a number of positive results on the lives and

Names 50.2 (June 2002):133-153

ISSN:0027-7738

(C) 2002 by The American Name Society 


\section{Names 50.2 (June 2002)}

writings of these poets. The sobriquets they created and used are not masks nor symbols of invisibility, but rather they provide alternate identities for these women, personae who inhabit a world in which women have control, who have the power of naming and thus the power of creation.

The use of sobriquets is a characteristic of British literature of the 16 th and 17 th centuries. It was common practice for writers in a literary or political coterie to give each other names which often defined, described, or characterized them, at least from the writer's perspective. The origins of this practice are unclear but one impetus was likely the era's fascination with such allegorical narratives as Spenser's Faerie Queene and Bunyan's Pilgrim's Progress, where names played similar but more obvious roles.

While there were earlier instances of this practice, the multiple sobriquets associated with Queen Elizabeth provided perhaps the most dramatic and focused example; these names were given in order to glorify, shape, and enhance her image as a monarch and as a woman among her courtiers and to her subjects. Spencer remarks on his use of these sobriquets in his "Letter of the Authors," prefaced to The Faerie Queene where he explains to Sir Walter Raleigh that he wishes to represent his queen in two ways, both as Gloriana, "the most glorious person of our soveraine the Queene, and her kingdome in Faery land;" and as "a most vertuous and beautifull Lady, this latter part . . . I doe expresse in Belphoebe, fashioning her name according to your owne excellent conceipt of Cynthia, (Phoebe and Cynthia being both names of Diana)" (quoted in Smith and deSelincourt 1966, 407). In addition to Raleigh's Cynthia and Spenser's Gloriana and Belphoebe, Elizabeth is referred to by other courtiers as Astrea and Laura; she is given additional names by her subjects as the primum mobile in the chain of love.

Sobriquets of the time are found in many different genres: the pastoral, the sonnet, and the Romance, as well as in private and public letters. Edmund Spenser-very self-consciously-names himself Colin Clout in The Shepheardes Calender. He explains in a note that Colin Clout is the name "under which . . . this Poete secretly shadoweth himself, as sometime did Virgil under the name of Tityrus, thinking it much fitter, than such Latine names, for the great unlikelyhoode of the language" (Smith and deSelincourt 1966, 422). This unusual note in which Spenser simultaneously reveals his identity and asserts that it is 
secret provides an early example (1579) of the ways in which British poets use the sobriquets, not as masks, but as a means to an alternate identity, one in which they define and control the terms of their activities.

Sir Philip Sidney's sonnet sequence, Astrophil and Stella (1591), provides another example of the use of sobriquets in the late 16th century. Sidney's sonnets of this series were written for a small coterie audience and they contain a number of playful masks and literary puzzles. The title sequence means 'star lover' and 'star', respectively, and while it is clear that Sidney is naming himself Astrophil, the identity of the beloved Stella has not been confirmed (although Penelope Devereux is the likely choice). Astrophil and Stella would certainly have been known to Katherine Philips, Aphra Behn, and Anne Finch, who would have seen in it a model for their own work, including its use of sobriquets and the way they simultaneously reveal and conceal identities.

Among the many additional instances of the use of sobriquets in this period is Mary Wroth's Urania (1621). This is a very long Romance; the first part over 350,000 words and the second part some 240,000 . It focuses on the good queen Pamphilia's love for her inconstant cousin Amphilanthus, "the lover of two." Pamphilia's friend and counselor, Urania, chides her for her constancy. The third major figure of the work is Veralinda. These three women are the poets and the artists of this Romance, and as such they represent the higher virtues. Urania contains many references to contemporary court intrigues, some so thinly disguised that Wroth volunteered to withdraw her work because of the scandal it caused when the people behind the sobriquets were readily identified. This work, well known in the 17 th century, would have provided a cautionary note to Philips, Behn, and Finch. By their use of sobriquets they could create alternate worlds, with women at their centers. However, even in those fictional worlds, the writers had to be wary of the connections likely made by their audience to the events in the world around them.

The origin and shifting nature of women's names have created a number of problems for women and for those of us who examine the lives of women in history. Many young women have regarded their names as temporary, names their parents gave them to serve only until their husbands provided permanent names. Also, problems with the biographical material (with Aphra Behn in particular) illustrate the 


\title{
136 Names 50.2 (June 2002)
}

difficulties of following a woman's life if her original name was uncertain and her name subsequently changed (Jones 1995). As in other areas of their lives, women in the 17 th century had little control over their names; they did not have the power to name themselves, their friends, or even their children. In 1664 Margaret Cavendish, the Duchess of Newcastle, wrote

\begin{abstract}
a woman's name is lost as to her particular in her marrying, for she quits her own and is named as her husband; also her family, for neither name nor estate goes to her family according to the laws and customs of this country ... . [S] [Se hazards her life by bringing [children] into the world, and has the greatest share of trouble in bringing them up [but mothers cannot] assure themselves of comfort or happiness by them, when they are grown to be men, for their name only lives in sons, who continue the line of succession, whereas daughters are but branches which by marriage are broken off from the root from whence they sprang, and ingrafted into the stock of another family, so that daughters are but moveable goods or furnitures that wear out . . . (1985, 183-84)
\end{abstract}

A second aspect of the problem of names and naming involves women as writers, since at the time, female virtue demanded namelessness. The adage, "Fools' names, like fools' faces, always seen in public places," applied with a vengeance in 17th century England. Whereas Ben Jonson wanted to "make a name" for himself, women should not, must not, have their names bandied about in public. Fame for women was associated with notoriety and promiscuity. Katherine Philips' letter of 1663 in response to the unauthorized publication of her poems reveals her fear of such notoriety:

I have rather endeavoured never to have those trifles seen at all, than that they should be exposed to all the world in this impudent manner in which they now most unhappily are. But is there no retreat can shield me from the malice of this world? . . I am the only unfortunate person who cannot so much as think in private, who must have all my imaginations and idle notions rifled and exposed to play the mountebanks and dance upon the ropes to entertain the rabble, to undergo all the raillery of the wits, and all the severity of the wise, to be the sport of some that can, and derision of others that cannot read a verse. This is the most cruel accident that could ever have befallen me . . . $(1985,196)$

Philips clearly accepts society's view that publication represents a cheapening of a person, that to be published is to be exposed in a gross and lewd way. 
Aphra Behn did not accept society's determination that women should not, must not be public figures. She was a prolific writer who wrote in her own name, and she paid dearly for it. Her reputation, in brief, was that of a lewd, promiscuous woman. John Duncombe is probably referring to Behn when he compares the "chaste Orinda" (Katherine Philips) with the "train of shameless bards, licentious and profane" $(1754,12)$. In comparisons between the writers made at the time, Philips is the chaste one, Behn the immoral one. Even Anne Finch, in describing the women poets of her time in "The Circuit of Apollo," comments (perhaps deliberately ambiguously) that Behn wrote "too loosely" (Reynolds 1903, 92).

Margaret Ezell warns scholars of the early modern period to be wary of the public versus private distinction regarding literary fame and reputation. She notes that, although these public and private categories are valuable in looking at the 18th century and later, in a "preprofessional literary environment, to publish was the exception for both men and women, and the most common practice was the circulation of manuscript copies" $(1996,37)$. Her caution is important since many of the writers in the 17th century-women and men-did not seek publication until they had already achieved fame through circulating their works in manuscript. But the intensity of Katherine Philips' statements about publication and the stark contrast between the contemporaneous reputations of Philips and Behn provide evidence for the ways in which publication threatened women writers with an intensity greater than that of the threat to men. This difference is likely related to the tendency to equate publication and promiscuity, especially for women.

Ezell $(1996,37)$ further notes that coterie literature, especially as the concept applies to the writings of Philips and Finch, must be regarded as a "legitimate literary outlet" since it is the primary arena for their writings and obviously a valuable one. The circulation of poems and letters to a group of friends creates the primary audience for their writings; even Behn has her "cabal," just as Philips and Finch have their coteries. While recognizing the validity of Ezell's reminder to respect the "pastness" of the past, it is important to underline the gender differences in 17th century British society's attitudes toward publication and recognition in the public sphere.

Traditionally women have attempted to solve the problem of their tainted identities as persons and as writers in the public sphere in several ways. Some made themselves invisible, giving up their identities in 


\section{Names 50.2 (June 2002)}

order to be taken seriously as writers. Some circumvented the problem by writing anonymously or generically, by publishing, as many did, simply as "a lady," while others choose pseudonyms. ${ }^{1}$ Madeleine de Scudery wrote under her brother's name, as did the Countess of Pembroke, whose brother was Sir Philip Sidney. In the 19th and 20th centuries women often used masculine pseudonyms or initials to camouflage their gender and to gain access to the male arena and so to the male authority as a writer. Most 17 th and 18th century women writers took a different route and chose sobriquets, but ones which revealed their gender.

The sobriquet, unlike other forms of naming, at least partially solves the problem of invisibility as well as the problem of notoriety. Since the women name themselves and rename the individuals to whom they write their poems, they take to themselves the power of naming, the power of creating and shaping identity. The names also serve to separate the women's identities as writers from their societal roles as daughters and wives. The women are known within their community, within the group which affirms them, but they are able to remain anonymous in the outside-and often hostile-world of published writing. Also, women naming themselves gives precedence to their roles as writers. When they use sobriquets, they are writers first and all other identities are secondary. The sobriquets are thus not masks or symbols of invisibility which provide anonymity, but rather they provide alternate identities for these women, identities in a world in which they are connected with one another and confirmed as writers.

\section{Aphra Behn}

Aphra Behn uses at least 33 different sobriquets in her poetry. Several of these names, such as Ceres and lris (Todd 1992, 63, 170), are general references to figures in the literary tradition, but Behn used names primarily as a description of her writing persona and as laudatory or whimsical labels for her friends and lovers. The primary source for these names is a French prose romance by Honoré D'Urfé, L'Astrée (Paris, 1614), translated anonymously as The History of Astrea (1620) and as Astrea, A Romance (1657). This was an enormously popular work of some 5,500 pages. Steven Rendall, the editor of a 1997 translation, contrasts the life of D'Urfé in 17th century France with the world of Astrea: "Perhaps this tale of civil war, exile, and death helps us understand why D'Urfé and his contemporaries found the peaceful world 
of pastoral romance so attractive" (xii). The central narrative which frames the work is the love story of Celadon and Astrea, shepherds whose love is stormy but steadfast. Book One of Part One begins with an episode in this tale of forbidden love. When Astrea falsely charges Celadon with unfaithfulness, he jumps into the river Lignon. Thinking he is drowned, Astrea faints and falls into the water. The remainder of Part One describes their continuing search for each other and ends with Celadon returning to the place where he and Astrea fell in love. Here he discovers a letter from Astrea which anticipates the lovers' eventual reunion. Behn read this work while in Surinam (Goreau 1980, 54; Duffy $1977,40)$ and she used the names from this romance throughout her life in her letters, her poetry, and her plays. She first used the names of the hero and heroine, Celadon and Astrea, to refer to her beloved, Thomas Scot, and to herself while she was in Surinam (Duffy 1977, 40, 45). The character of the chaste shepherd Celadon bears little resemblance to that of Thomas Scot, whom Janet Todd and other Behn biographers describe as a promiscuous older man, probably married (Todd 1997, 51). Behn's use of Celadon as Scot's sobriquet is best seen as part of her creation of an alternative romantic world, one in which men and maids were chaste, faithful and loving. In later writings Behn continues to recreate the world of the French romance by giving members of her cabal the names of D'Urfé characters.

In Behn's poem "Our Cabal" (Todd 1992, 47) each stanza is addressed to a different member of her circle and within the text of that stanza the pastoral name is used. Each person is described in her or his section of the poems with elaborate language and extravagant pastoral conventions. For instance, Elizabeth Berry, the prominent London actress, is brought forward and described:

Next, Amoret, the true Delight

Of all that do approach her sight:

The Sun in all its Course ne'er met

Ought Fair or Sweet like Amoret. (Todd 1992, 48)

In an earlier poem, Behn had warned Amoret against the duplicitous Amyntas, a man who will try to trap her, but one she can overcome since she has "Charms that will secure / A Captive in this Conquerour." Elizabeth Berry was a close friend of Behn's and acted in several of her plays. She was a wealthy and successful actress for three decades at the end of the 17th century. Berry is characterized in these poems as a 


\section{Names 50.2 (June 2002)}

charming and confident woman, one who exerts positive control over her friends and lovers.

Amyntas is one of the most frequently occurring names in Behn's pastoral repertoire; she uses the name in 15 different poems. Most of the time the name refers to John Hoyle, a London lawyer with whom Behn had a relationship in the 1670s. In the Amoret poem mentioned above, the title, "A Ballad on Mr. J. H. to Amoret, Asking Why I was so sad" reveals that the Amyntas of the poem is John Hoyle. Amyntas appears as the title character in two Thomas Randolph plays, Amyntas and Urania and Amyntas or the Impossible Dowry (1638). The latter play, adapted for the stage by Behn, is a combination of Italian pastoral romance and British comedy. In this work Amyntas goes mad because he loves Urania desperately but cannot marry her because he is not wealthy enough. After he is cured of his madness, Amyntas solves the love difficulties of the other pairs of characters, Damon and Amarillis, and Alexis and Laurinda. Amyntas speaks:

Ceres. I doe thank thee,

That I am author of this publique joy:

But is it justice (Goddesse) I alone

Should have no share in't? Every one I see

Is happy but my self that made 'em so,

And my Urania that should most be so. (Perry 1917, 347)

Amyntas then goes to the goddess Ceres and pledges himself as Urania's dowry; she accepts the pledge. Urania makes the identical pledge and there is a happy ending for all concerned.

Behn also inscribes "The Return" (addressed to Amyntas), "To J. Hoyle, Esq" (Todd 1992, 59, 391). In this poem, Amyntas is a very different shepherd than the character in Randolph's play. Here he "can conquer a Heart with a Look or a Smile." He is "pityless" and has "no Faith." So while Behn positions Hoyle in the pastoral world of true love, he retains some of his London Restoration characteristics; with his "soft warring eyes," he is a ladies' man who has conquered all (Todd 1992, 59). Several other Amyntas poems have a similar inscription and some contain contextual evidence which suggests John Hoyle (Todd $1992,284,433)$. In all of these poems Hoyle is described as a charismatic man, one who woos and wins almost all who come within his sphere; Elizabeth Berry alone is able to resist his attempts at seduction. It is appropriate that he should be given the name of the protagonist of 
a comic pastoral, one with birds who speak not Greek and Latin but "Cawation, Chirpation, Hootation, and Whistleation" (Perry 1917, 244). Amyntas' world, for all his madness, is a forgiving world, one in which the problems of lovers are easily solved. Using Amyntas as a sobriquet for Hoyle is a whimsical kind of compliment; Behn is once again laughing at him, at herself, and at her circle, but in a Horatian satiric manner.

In "The Cabal," however, Behn does not use the name Amyntas to refer to Hoyle; rather, Jeffrey Boys is given this name:

Mr. J. B.

Next jolly Thirsis came along

With many Beauties in a Throng.

Mr. Je. B

With whom the young Amyntas came,

The Author of my Sighs and Flame:

For sure no Nymph was ever free,

That could Amyntas hear and see. (Todd 1992, 48-49)

John Hoyle has been supplanted by Jeffrey Boys as the beautiful young man by whom the nymph will be "Undone;" he has been relegated to a "Lysidas,"

that haughty Swain

With many beauties in a Train,

All sighing for the Swain, whilst he

Barely returns Civility.

Yet once to each much Love he Vowd,

And strange Fantastique Passion show'd. (Todd 1992, 51)

Hoyle, is no longer the attractive, intelligent lover Behn described in the "Amyntas" poems; in these lines he is presented as arrogant, fickle, and barely civil in his manner. Behn continues "The Cabal" by describing the attraction which Lysidas exerts on the men in the group as well as the women: he continues to grow more beautiful since he basks "under two such Suns as those" (Todd 1992, 52). Behn suggests that the "two Suns" are the women and the men of his circle. By switching Hoyle's sobriquet from Amyntas to Lysidas, Behn is changing his image, shifting his identity, and so exerting some power over him, or at least over her attitude toward him. 


\section{Names 50.2 (June 2002)}

Behn evokes the idyllic world of the pastoral romance by choosing her names not only from D'Urfé but also from other well known romances and pastorals of the period. Strephon, the loveliest of shepherds in L'Astrée, is John Wilmot, Lord Rochester, but Amarillis appears in the works of Spenser, Fletcher, and Buckingham. Aminta is the title character in Tasso's romance; Amoret is a character in Fletcher's The Faithful Shepherdess. Fletcher and Middleton's plays and Sidney's Arcadia are additional sources for these names. These elegant pastoral figures populate a world very different from the London of the plague and the fire or the London of the theater and the Restoration court. With these names Behn moves herself and her friends into an alternative world, in which she is the creator as well as the chronicler.

In addition to her use of names from romance, Behn also uses typical names, as Goreau and others have suggested $(1980,275)$. Some of her poems employ the pastoral names in conventional ways. She writes several songs consoling Aminta, who is languishing for her lost lover and exhorting Phillista to "seize the day." But most of her names are more than types; they are imaginative recreations of her friends and lovers. We, as readers, realize that Behn is transforming these persons by naming them and so giving them different lives.

Whatever the rationale behind Behn's choice of names for her friends, her self sobriquet is especially important in framing her identity. Although she sometimes names herself Aminta, she usually refers to herself as Astrea. Here she chose a name with multiple and positive connotations: the name of the heroine of D'Urfe's French romance Astrea, literally 'star' and associated with Queen Elizabeth and with the "ambivalent virginal but fecund goddess of justice" (Todd 1992, ix). It is through this name that she can combat the conventions of the time, the negative responses she receives as a woman writer. In a manifesto attached to her play, The Lucky Chance, Behn pleads for an equal opportunity:

And this one thing I will venture to say, though against my nature, because it has a vanity in it: That had the plays I have writ come forth under any mans name, and never known to have been mine; I appeal to all unbiased judges of sense, if they had not said that person had made as many good comedies, as any one man that has writ in our age; but a Devil on't, the Woman damns the poet. (Goreau 1980,264) 
Introducing her play, The Dutch Lover, Behn makes a similar point in the epistle to the reader, whom she characterizes as "Good, Sweet, Honey, Sugar-Candied Reader." This letter argues mockingly that women can indeed write good plays, because plays don't demand "learning"-the area in which men are superior to women (Summers 1967, 221-25).

Writing as Astrea in the poem "On Mr. J. H. In a Fit of Sickness," Behn pledges her love to her "Amyntas," John Hoyle, and admonishes him to "Revive, come forth, be Gay and Glad;" she curses his disease while alluding to her identity as a writer:

In Pity to Astrea live,

Astrea, whom from all the Sighing Throng,

You did your oft-won Garlands give:

For which she paid you back in Grateful Song:

Astrea, who did still the Glory boast.

To be ador'd by thee, and to adore thee most. (Todd 1992, 90)

Here Behn places Hoyle as Amyntas in her pastoral world, the world of Cupid's darts, love-sick maids, flocks, and cooling streams. She herself lives in that world as Astrea, the lovesick nymph who sings her poems to her beloved.

With her persona of Astrea, the woman poet, Behn also places herself in the tradition of Sappho and of Katherine Philips, the "matchless Orinda." Behn writes:

I by a double right thy Bounties claim,

Both from my Sex, and in Apollo's Name:

Let me with Sappho and Orinda be

Oh ever sacred Nymph, adorn'd by thee:

And give my Verses Immortality. (Todd 1992, 325)

Behn will not be forced to choose between being a woman and a poet; she claims both, as a double right. Her writings reveal her ambivalence about her gender and its roles, but her refusal to write anonymously, her continual assertion of her right to write and her designation of herself as the "star" reveal a deep self-confidence. 
Anne Finch

Anne Finch lacked the confident, gregarious identity of Aphra Behn, but, like Behn, she also named herself and defined herself by her choice of names. Her first self-chosen name, Areta, appears on early manuscripts; these were changed after her death by her husband, Heneage Finch. Areta, in a manner similar to that of Astrea, connotes strength and endurance. The word itself is probably derived from Greek arete, which meant 'courage' and later 'virtue'. In the Odyssey, Arete is the wife of Alcinous, King of the Phaeacians, a woman who was a noble and active superintendent of the household. Ben Jonson in Cynthia's Revels, or The Fountain of Self-Love gives the name to a lady who personifies virtue and reason. Jonson's Arete is a beautiful, high-minded nymph, one who argues against the frivolity of Cynthia's courtiers; Arete encourages them to present "solemne revels" for Cynthia, and is ridiculed for her sober advice although she is Cynthia's favorite, the one who-with Crites-prevails over the other courtiers (Brock 1983, 12).

The young Anne Kingsmill, before her marriage to Heneage Finch, probably anglicized the name from Greek arete through French, since it was the practice of the time to change the final $e$ of French names to $a$, and took it for her own. So D'Urfé's Astrée became Astrea, just as French Silvie in the same romance became English Silvia and as French Chimene became Cimena, the sobriquet Philips uses for Mary Carne.

Sometime in the 1690s, after Finch was married and had retired to Eastwell where she began her serious writing, she renamed herself Ardelia. This is not a common pastoral name of the type used by Aphra Behn; it is in fact an unusual name, found only in a few works such as James Shirley's The Duke's Mistress (1636) and John Fletcher's The Tragedie of Valentinian (performed c. 1612). These do not appear to be the source of the name for Anne Finch, however; rather, it is likely from a poem by Katherine Philips, "A retir'd friendship to Ardelia:"

Come, my Ardelia, to this bower,

Where kindly mingling souls awhile,

Let's innocently spend an hour

And at all serious follies smile.

.... In such a scorching age as this,

Who would not ever seek a shade

Deserve their happiness to miss,

As having their own peace betrayed. 


\section{Women Naming Women 145}

But we (of one another's mind

Assured) the boisterous world disdain;

With quiet souls and unconfined

Enjoy what princes wish in vain. (Philips 1987, 373-74)

By choosing the name Ardelia, Finch recognizes her debt to Katherine Philips, and she also characterizes herself, as she does in a number of her poems, as one who will be "in retirement, [and] . . . can bless the shade" (Reynolds 1903, 15). In "The Introduction," Finch writes

Be caution'd then my Muse, and still retir'd;

Nor be dispis'd, aiming to be admir'd;

Conscious of wants, still, with contracted wing,

To some few friends, and to thy sorrows sing;

For groves of Lawrell, thou wert never meant;

Be dark enough thy shades, and be thou there content.

(Reynolds 1903, 6)

Barbara McGovern agrees that Philips' poem is the most likely source for Finch's Ardelia $(1992,143)$. Finch was a great admirer of Philips' poetry and there are frequent references to Philips throughout Finch's work. Finch fashions her use of pseudonyms upon the pattern of Philips who often gives her friends pastoral names and praises their retirement from the busy life of the city.

Finch and Philips are both writers who struggle with the public image of a woman poet, and Finch takes Philips' lead in accepting the retired life as the better choice. There is a tension in Finch's poetry about the retired life, however. Philips' portrayal of life away from the "slavery of state" is unequivocally positive but she seems to be making the best of a necessary evil. In both "The Introduction" and "An Apology," she reveals her anger against a society which refuses to recognize the artistry of works "by a woman writt." Yet both Philips and Finch view the life of retirement with a few friends who support their poetic personae as the best option for a woman writing at the time.

Finch subsequently abandoned the name Areta, which associated her with the epic tradition of Homer and with particular character traits. In "The Critick and the Writer of Fables," Finch directly states her impatience with the Homeric tradition and places herself instead in the pastoral world: 


\section{Names 50.2 (June 2002)}

I'm sick of Troy, and in as great a Fright, When some dull Pedant wou'd her Wars recite, As was soft Paris, when compell'd to Fight.

To Shades and Springs shall we awhile repair,

The Muse demands, and in that milder Air. (Reynolds 1903, 154)

The name Ardelia is much more appropriate for a writer of lyric poetry, of pastorals and fables, or one who denies the epic form as the pinnacle of the hierarchy of genre. Finch renames herself Ardelia, associating herself with the tradition of women writers and with escape to a pastoral life which focuses on friendship rather than domesticity, on writing rather than politics, and on lyric or pastoral poetry, rather than the epic. Both Finch and Behn use names from the pastoral and the romance rather than the Homeric tradition. Astrea, however, at times chooses to live in the public world of the London stage, whereas Ardelia usually describes herself as one who lives quietly in retirement.

In her poetry, Ardelia uses a number of names common to the romances and pastorals of the period (as did Behn). Phillis and Silvia appear repeatedly in Ardelia's songs and verses. She also accepts several of the names associated with her friends and writes to them using those names; she describes Elizabeth Singer as Philomela and Mary of Modena as Urania. The use of sobriquets was a common practice in this period among the aristocracy, so it is not surprising that Finch recognized and used these names given her friends by others. She names her husband, Heneage Finch, both Flavio and Dafnis. Dafnis is a reference to the shepherd whom Pan taught to sing and play the flute and is said to have originated bucolic poetry; Finch regards her husband as one of the major subjects and muses of her poetry.

The names which Finch chooses for her friends are generally more difficult to trace than those used by Behn. The name Armida appears in Tasso's Jerusalem Delivered (1580) and is the title of an opera by Lully (1686); Mira is a name used for Queen Elizabeth and appears in Spenser's Faerie Queene; and Theanor is the lover of Aurelise in de Scudéry's novel Clelie (1654-60). But it is difficult to affirm any connection between these sources and Finch's work, especially since there is no single source which provides several of the names, as was the case with Behn and L'Astrée. In general Finch chose more unusual names when writing about her friends; she didn't repeat these names, and the sources of the names were more varied. 
Finch's choice of names for the women poets of her time is especially noteworthy. In her "The Circuit of Apollo," a parody of the judgement of Paris, Apollo comes to select and bestow the laurel wreath upon the greatest living woman poet. But only four women poets appear in response to his decree: Alinda, Laura, Valeria, and Ardelia. Apollo grieves that Behn is not among them:

He lamented for Behn o're that place of her birth,

And said amongst Femens was not on the earth

Her superiour in fancy, in language, or witt,

Yett own'd that a little too loosely she writt;

Apollo continues his deliberations after Orinda joins him in the heavens and ultimately decides to give the wreath to all:

they all had a right to the Bay's,

And that 'twere injustice, one brow to adorn,

With a wreath, which so fittly by each might be worn. (Reynolds 1903, 92-94)

The names Alinda, Laura, and Valeria are more difficult to identify than might at first appear. Alinda is a character in Thomas Lodge's Rosalynde. a source for Shakespeare's As You Like It. She also appears in two of Fletcher's plays, The Pilgrim (1622) and Loyal Subject (1618). Is she one of Finch's friends? Perhaps Mrs. Randolph? The identity of the other two women is equally unclear. Laura is a name often used to describe Queen Elizabeth, the virgin queen; it is also, of course, the name of Petrarch's beloved and so one of the muses of poetry. Laura was a name often associated with Mary of Modena, the wife of James, Duke of York, who was Finch's patron. But why the name Laura in this context? Valeria is another common heroic name, used often in plays and romances of the period. She is a character in Shakespeare's Coriolanus, in de Scudéry's Histoire d'Herminius et de Valerie, and the protagonist in Middleton's The Widow (1652). The name is used by Katherine Philips as a sobriquet for Anne Boyle and is the heroine of Behn's The Rovers (1677). The names thus have a rich history in 17th century literature, but we have no concrete evidence which connects any of them specifically to Finch and her circle. Since Finch is usually specific with names and since she frequently makes quite clear to whom the names refer, it is quite possible that here she is deliberately using general sobriquets. In "The Circuit of Apollo," where she writes that 


\section{Names 50.2 (June 2002)}

there are only four living women poets in England, she makes those four poets herself and three omnipresent women: women whose names carry very strong, positive connotations but cannot be tied to any specific person. These names, then, encompass all the women writers, all the women whose names have been lost. They could obliquely refer to poets such as Anne Killigrew, one of Mary of Modena's ladies-in-waiting and the one whose poetry was praised by John Dryden, and the still unidentified woman poet who used the name Ephelia.

\section{Katherine Philips}

Chronologically Katherine Philips precedes both Aphra Behn and Anne Finch, and her work is regarded by them as the standard for their own poetry. In "The Circuit of Apollo," for instance, Finch places Katherine Philips in the heavens with Apollo, rather than on earth with the others. In a number of commendatory poems Philips is described as the English Sappho, the preeminent woman lyric poet of the time. Nahum Tate in his commendatory poem unites Aphra Behn with the two great lyric poets Sappho and Orinda:

The pride of Greece we now out-rival'd see:

Greece boasts one Sappho; two Orinda's we. (Summers 1967, VI, 7)

Philips' poetic use of pastoral names and sobriquets for her friends includes patterns used by both Behn and Finch. At times she uses typical names and employs the conventions of pastoral poetry. Like Anne Finch, Philips normally uses only one name for each person and the names Philips chooses are not primarily from any one source. Whereas both Behn and Finch rely on the romances and pastorals of the time. Philips draws many of her sobriquets from heroic figures of classical Greece and Rome. Her name for her husband, James Philips, is Antenor, the Trojan elder who advised against returning Helen to the Greeks. She gives Cicily Philips the name Cassandra and refers to Lady Anne Boyle as Valeria.

Lucasia, Rosania and Orinda are Philips' most distinctive sobriquets. These are the names she gave to her two best friends and to herself. Each of these names appears repeatedly in her poetry. Lucasia appears in 25 poems; 15 poems are to and about Rosania; and there are 14 poems in which Philips refers to herself as Orinda. Each of these names is unusual in one respect or another. Lucasia, Philips' name for 
Anne Owen (later Anne Trevor) appears only once in the literature of the time, as the name of the Princess of Cypress, the romantic heroine of William Cartwright's The Lady Errant (c. 1633-35). In his edition of The Plays and Poems of William Cartwright, G. Blakemore Evans argues that Katherine Philips knew Cartwright's work very well and that she provides a link between him and Dryden $(1961,53)$. Philips did select several of her sobriquets from the character names in Cartwright's plays, including Cratander for John Berkenhead, Charistus for John Owen, and Lucasia for Anne Owen. Philip W. Souers in his biography of Philips points out echoes of the lines of Cartwright's Lady Errant in her poetry (Evans 1961, 52). The romantic heroine of this play had the name Calanthe in the earlier version and Lucasia in the later version. Philips uses both of these names to refer to Anne Owen. Evans argues that this parallel suggests that Katherine Philips may have "had a hand" in making the name change in the later version of the play $(1961,53)$. Whether or not Evans is correct, the parallel does provide convincing evidence that Philips is using the name of Cartwright's heroine for her friend Anne. Lucasia and her beloved Charistus provide the love interest in Cartwright's play. The play itself turns on a Lysistrata theme in which the women plan to take over the city from the men, so it contains many references to Amazon women, to the foolishness of men and to women's strength. Queen Adraste's address in Act IV, Scene I is typical:

My Lady Martiall, and the rest Mercuriall, Woman's the Gem of Heaven, in which Nature

Hath carv'd the universe in less Characters;

A Peece of such Invention, and such Art,

That, where as in one common lazy Mold

Made for dispatch, she casts, and thrusts out Men,

As some things done in haste, she may be said

To build, and send forth us. . . . (Evans 1961, 131)

The world that Lucasia inhabits, then, is one of strong women and loving men. In selecting this name, Philips is creating a special identity for her friend, Anne Owen. She is no longer Anne and the shifting family names are ignored. Anne's husband John is given the parallel name from the Cartwright play; so instead of Anne and John, Orinda names them Lucasia and Charistus. Orinda and Lucasia reside in the 
world of Philips' poetry and letters as friends and companions, part of a romantic pastoral, separate from the world of men.

Rosania is Philips' name for her friend, Mary Aubrey. This is an unusual name and I have found only one reference, that of the heroine of James Shirley's Rosania (performed 1640). (Shirley's play is better known by its later title, The Doubtful Heir, published in 1652.) In the 1640 version of the play, Rosania, or Love's Victory, the playwright provides a prologue in which we find possible sources for the name:

Rosania? Methinks I hear one say, What's that? "Tis a strange title to a play.

One asks his friend who late from travel came,

What 'tis? Supposing it some country's name;

Who, rather than acknowledge ignorance,

Perhaps says, 'tis some pretty town in France

Or Italy, and wittily discloses,

'Twas call'd Rosania, for the store of roses.

A witty comment: -others, that have seen,

And fashionably observ'd the English scene,

Say, (but with less hope to be understood)

Such titles unto plays are now the mood,

Aglaura, Claricilla,-names that may

(Being ladies) grace, and bring guests to the play. (Dyce 1833,

278)

Shirley may be mocking those of us who seriously trace names (often laboriously) in an attempt to determine their sources. I can find no direct evidence that Philips knew this play, although it is certainly possible that she was familiar with it or at least with its title. The eponymous heroine is a character very similar to Viola in Shakespeare's Twelfth Night. Rosania disguises herself as a page, is beloved by both her lord and her lady, and must by her wits and, with the help of her beloved, Ferdinand, who is aware of her real identity throughout the play, extricate herself from her dilemma. Some of the other names in the play, such as Olivia and Violinda, signal the play's indebtedness to Shakespeare's earlier version of the story. The Rosania of Shirley's play is certainly a worthy candidate to bestow her name on Orinda's friend, Mary Aubrey. 
No one has been able to locate any sources for the name Orinda. It is possible that Katherine Philips created this name, a sobriquet which had no history but was her name only. Aphra Behn gave herself several names with strong, clear allusions to powerful figures from French romance. Anne Finch in her maturity chose to name herself as one of Katherine Philips' coterie, one who had retired to the shade. But Philips designates herself by a unique sobriquet, a name which she shares with no one, either in literature or in life.

\section{Conclusion}

Katherine Philips employs names from the epic tradition as well as from the pastoral and romance. Her sobriquets for her husband and for some of her friends are taken from the world of the epic. Her own sobriquet, Orinda, and those of her two closest friends, Lucasia and Rosania, all belong to the world of the pastoral. Philips' Ardelia poem, with its praise of the quiet life, the life of retirement in the shade, also suggests the pastoral. Anne Finch uses few names from the world of the epic and populates her poetic world with characters from the pastorals. She does, however, through the sobriquets, associate the women poets of her generation with Apollo, as well as with Queen Elizabeth and Mary of Modena. The heroic dimension of these figures adds stature to the practice of poetry. Aphra Behn selected her names primarily from the great French romance, Astrea. This source provides her friends with an alternative existence, one full of romantic adventure and pastoral serenity. The use of the sobriquets thus provides all three poets with a special kind of power, the power of the name. Each writer names herself and her friends and by so doing transcends the undesirable, often debilitating alternatives of invisibility or notoriety. Instead the writer identifies herself and her friends as inhabiting a different world, a world of recognition and community, of adventure and serenity.

\section{Notes}

1. The identities of some remain mysterious to this day; there is still speculation about the identity of "Ephelia," who published Female Poems on Several Occasions in 1679. Early scholarship suggested that she was Joan Philips, the daughter of Katherine, but recently Maureen Mulvihill (1995) has argued that she is Mary (Stuart née Villiers), the Duchess of Richmond and Lennox. 


\section{References}

Brock, D. Heyward. 1983. A Ben Jonson Companion. Bloomington: Indiana Univ. Press.

Cavendish, Margaret. 1985. "Selections from Sociable Letters." The Whole Duty of a Woman: Female Writers in Seventeenth-Century England. Ed. Angeline Goreau. Garden City: Doubleday.

Duffy, Maureen. 1977. The Passionate Shepherdness: Aphra Behn. London: Jonathan Cape.

Duncombe, John. 1754. The Feminiad: A Poem. London: Globe.

Dyce, Alexander, ed. 1833. "The Doubtful Heir." The Dramatic Works and Poems of James Shirley, IV. London: John Murray.

Evans, G. Blakemore, ed. 1961. The Plays and Poems of William Cartwright. Madison: Univ. of Wisconsin Press.

Ezell, Margaret. 1996. Writing a Woman's Literary History. Baltimore: Johns Hopkins Univ. Press.

Goreau, Angeline. 1980. Reconstructing Aphra: A Social Biography of Aphra Behn. New York: Dial Press.

Jones, Jane. 1996. "New Light on the Background and Early Life of Aphra Behn." Aphra Behn Studies. Ed. Janet Todd. Cambridge: Cambridge Univ. Press. Pp. 310-20.

McGovern, Barbara. 1992. Anne Finch and Her Poetry. Athens: Univ. of Georgia Press.

Mulvihill, Maureen. 1995. "The New Candidate for Pseudonymous 'Ephelia': Mary Stuart (nee Villiers), Duchess of Richmond and Lennox (1622-1685)." Women's Writing 2: 309-311.

Perry, John Jay, ed. 1917. The Poems and Amyntas of Thomas Randolph. New Haven: Yale Univ. Press.

Philips, Katherine. 1985. "Letter from Orinda to Poliarchus." The Whole Duty of a Woman: Female Writers in Seventeenth-Century England. Ed. Angeline Goreau. Garden City: Doubleday. . 1987. "A Retired Friendship: To Ardelia." The Meridian Anthology of Early Women Writers. Eds. Katharine M. Rogers and William McCarthy. New York: Penguin.

Rendall, Steven, trans. 1997. Honoré D'Urfé: Astrea: Part One. Tempe, AZ: Medieval and Renaissance Texts \& Studies. 
Reynolds, Myra, ed. 1903. The Poems of Anne Countess of Winchilsea. Chicago: Univ. of Chicago Press.

Roberts, Josephine A., ed. 1983. The Poems of Lady Mary Wroth. Baton Rouge: Louisiana State Univ. Press.

Smith, J. C., and E. deSelincourt, eds. 1966. Spencer: Poetical Works. Oxford: Oxford Univ. Press.

Summers, Montague, ed. 1967. The Works of Aphra Behn, 1. New York: Phaeton Press.

Todd, Janet, ed. 1992. The Works of Aphra Behn, 1: Poetry. Columbus: Ohio State Univ. Press. . 1997. The Secret Life of Aphra Behn. New Brunswick, NJ: Rutgers Univ. Press. 